\title{
Analisis kesenjangan harapan dan kinerja lanskap jalan sebagai ruang terbuka publik saat car-free day di kawasan Renon, Denpasar
}

\author{
Yensa Margareth Tarigan ${ }^{1}$, Cokorda Gede Alit Semarajaya ${ }^{\star \star}$, I Made Adikampana² \\ 1. Prodi Arsitektur Pertamanan, Fakultas Pertanian, Universitas Udayana, Indonesia 80232 \\ 2. Prodi Destinasi Pariwisata, Fakultas Pariwisata, Universitas Udayana, Indonesia 80232 \\ *E-mail: coksemarajaya@unud.ac.id
}

\begin{abstract}
The Gap Analysis of Expectancy and Performance of Streetscape as Public Open Space during Car Free Day in Renon Area, Denpasar. The numbers of open public space in Denpasar City have not been able to meet adequate ratios with population growth and urban development. To overcome this problem, one of the efforts that has been made by the government is to utilize the existing infrastructure into a temporary open public space which is the Car Free Day (CFD) Program. The shifting space utilization and the increase of activities on the streetscape will affect people perceptions who go there. This study aims to evaluate the Car Free Day program in Renon area base on the visitor satisfaction and streetscape performance. The analysis methods used are Costumer Satisfaction Index and Gap Analysis. The results of this study indicate that there are still disparities between the expectancy from the visitors with the streetscape performance. Car Free Day's Visitor satisfaction rate in Renon area is $78.4 \%$ in the range of $77 \%<X \leq 80 \%$ which is "borderline". It means there are some unsatisfactory attributes and the performance needs to be improved.
\end{abstract}

Keywords: car free day, customer satisfaction index, gap analysis, streetscape

\section{Pendahuluan}

Car Free Day (CFD) atau dalam bahasa indonesia adalah hari bebas kendaraan bermotor (HBKB) merupakan salah satu wujud pelaksanaan Keputusan Menteri Negara Lingkungan Hidup nomor 15 tahun 1996 tentang program langit biru yang merupakan program pengendalian pencemaran udara. CFD telah diselenggarakan di beberapa kota antara lain Jakarta, Surabaya dan Denpasar. CFD di Denpasar pertama kali diselenggarakan tanggal 16 Agustus 2009 dan penetapan areal pelaksanaan CFD diatur dalam peraturan walikota Denpasar nomor 28 tahun 2013.

CFD dilaksanakan dengan menutup beberapa ruas jalan di kawasan Renon yang kemudian dimanfaatkan masyarakat sebagai wadah untuk melakukan aktivitas sosial, olahraga maupun rekreasi. Dalam perkembangannya, lanskap jalan yang dimanfaatkan sebagai wadah pelaksanaan CFD, muncul fenomena pergeseran pemanfaatan ruang yang ditimbulkan oleh peningkatan aktivitas sehingga diperkirakan akan mempengaruhi persepsi pengunjung.

Evaluasi perlu dilakukan untuk mengukur keberhasilan program CFD dengan membandingkan tingkat kepentingan atau harapan pengunjung dengan tingkat kepuasan atau kinerja lanskap jalan yang dirasakan oleh pengunjung. Tingkat kinerja (performance) lanskap jalan sebagai ruang terbuka publik sementara perlu diketahui agar lanskap jalan tersebut dapat dikatakan berhasil dengan fungsinya yang lain yaitu sebagai ruang terbuka publik. Hasil dari penelitian ini dapat dijadikan sebagai masukan dalam menata areal CFD. 


\section{Metode}

\subsection{Tempat dan Waktu Penelitian}

Penelitian ini dilakukan pada saat pelaksanaan Car Free Day di kawasan Niti Mandala Renon Denpasar. Pengambilan data dilakukan mulai dari bulan Desember 2017 sampai dengan bulan Februari 2018 (Gambar 1).

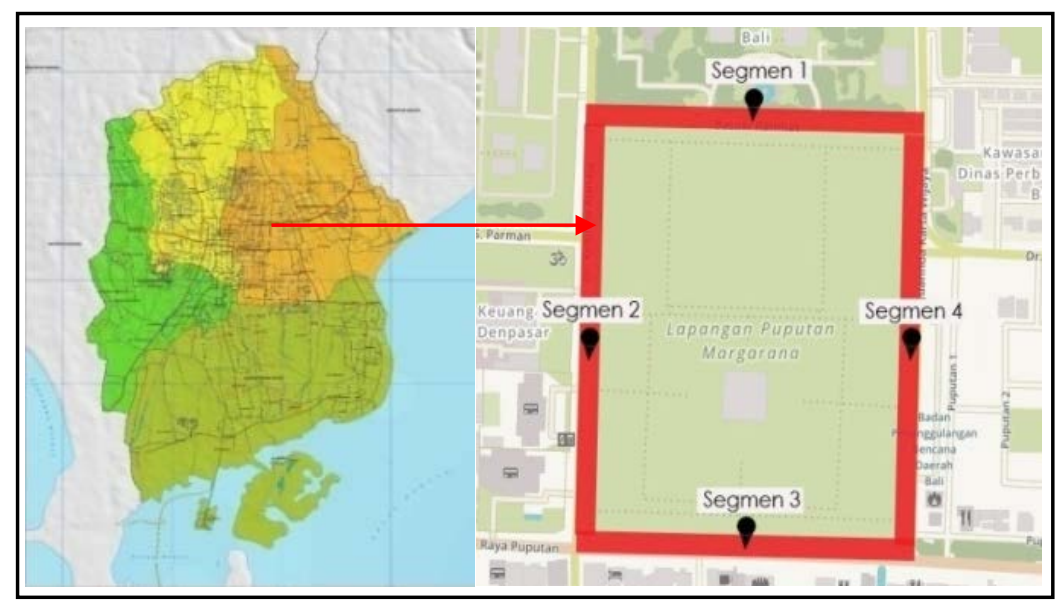

Gambar 1. Lokasi Penelitian

Sumber: DesignMap (www.opensreetmap.org)

\subsection{Alat dan Bahan Penelitian}

Alat yang digunakan dalam penelitian ini adalah lembar kuesioner, alat tulis, laptop dengan perangkat lunak Microsoft Word, Microsoft Excel, SPSS, AutoCAD dan Photoshop. Sedangkan bahan yang digunakan dalam penelitian ini meliputi pustaka ataupun literatur yang diperoleh dari berbagai instansi terkait.

\subsection{Metode Penelitian}

Penelitian ini adalah penelitian evaluatif karena dimaksudkan untuk mengukur keberhasilan suatu program kegiatan. Evaluasi dilakukan dengan menggunakan empat indikator yang merupakan empat kunci utama keberhasilan suatu ruang publik menurut Project for Public Space (2005) dan Carmona dkk (2003) yaitu kenyamanan dan kesan, akses dan hubungan, Fungsi dan aktivitas sosial, serta penemuan dan pengelolaan.

\subsubsection{Pengumpulan Data}

Kuesioner merupakan instrumen yang digunakan untuk mengevaluasi dengan menggunakan bobot skala Likert. Penelitian ini menggunakan dua variabel yaitu:

1. Variabel terikat merupakan variabel yang menjadi pusat perhatian utama peneliti yaitu: kepuasan pengunjung dan tingkat kepentingan/ kinerja lanskap jalan.

2. Variabel bebas merupakan variabel yang mempengaruhi variabel terikat yaitu: kenyamanan, kemudahan akses, tanda interpretasi, keterlibatan aktif, keterlibatan pasif, serta penemuan dan pengelolaan.

Setelah membuat pertanyaan kemudian menentukan jumlah sampel. Menurut Joseph F. Hair (dalam Poewarti dkk., 2016) jumlah sampel ditentukan dengan rumus 15 atau 20 kali variabel bebas sehingga didapat total 90 responden yang dibagi pada empat segmen jalan.

Selain melalui kuesioner, data juga dikumpulkan melalui observasi lapang yaitu analisis dan interpetasi lanskap jalan, dan studi literatur mengenai progaram CFD di Kawasan Renon. 
Tabel 1. Pembagian Jumlah Sampel

\begin{tabular}{ccccc}
\hline No & Lokasi & Nama Jalan & $\Sigma$ Responden (Jiwa) & Jumlah Sampel \\
\hline 1. & Segmen 1 (20\%) & Jl. Basuki Rahmat & 90 & 15 \\
2. & Segmen 2 (30\%) & Jl. Kusuma Atmaja & 90 & 30 \\
3. & Segmen 3 (20\%) & Jl. Raya Puputan & 90 & 15 \\
4. & Segmen 4 (30\%) & Jl. Juanda Kartawijaya & 90 & 30 \\
\hline \multicolumn{7}{c}{} & Jumlah & & 90 \\
\hline
\end{tabular}

Sumber: Hasil perhitungan, 2018

\subsubsection{Analisis Data}

1. Uji Validitas dan Reliabilitas

Menurut Hair (dalam Handriati dkk., 2015) Uji Validias dilakukan dengan tujuan sebagai petunjuk sejauh mana suatu alat pengukur (instrumen) mengukur apa yang diukur. Sedangkan Uji Reliabilitas adalah uji untuk mengetahui apakah hasil pengukuran tersebut dapat dipercaya untuk digunakan dalam pengumpulan data. Uji validitas dan reliabilitas dilakukan dengan menggunakani software SPSS 23 for Windows.

2. Customer Satisfaction Index (CSI)

CSI digunakan untuk mengetahui tingkat kepuasan pelanggan dengan memperhatikan tingkat kepentingan dari atribut-atribut produk atau jasa. Besarnya CSI dapat ditentukan dengan langkah-langkah

a. Menentukan Mean Importance Score (MIS) atau rata-rata skor kepentingan per atribut

b. Membuat Weight Factors (WF) atau faktor tertimbang per atribut.

c. Menentukan Mean Satisfaction Score (MSS) atau rata-rata skor kepuasan per atribut.

d. Membuat Weight Score (WSk) atau skor tertimbang per atribut.

e. Menghitung Customer Satisfaction Index (CSI) dengan menggunakan rumus:

$$
C S I=\frac{\sum_{i=1}^{p} W S_{i}}{H S} \times 100 \%
$$

Keterangan:

$\mathrm{WS}=$ Weight Score $(\mathrm{WS})$

i= Atribut Kepentingan ke-i

HS= Skala maksimum yang digunakan

Setelah didapatkan indeks kepuasan pengunjung, selanjutnya diinterpretasikan berdasarkan kriteria pada berikut.

Tabel 2. Customer Satisfaction Index Interpretation

\begin{tabular}{cc}
\hline Angka Indeks & Interpretasi \\
\hline$X \leq 64 \%$ & Very poor \\
$64 \%<X \leq 71 \%$ & Poor \\
$71 \%<X \leq 77 \%$ & Cause for concern \\
$77 \%<X \leq 80 \%$ & Borderline \\
$80 \%<X \leq 84 \%$ & Good \\
$84 \%<X \leq 87 \%$ & Very Good \\
$87 \%<X$ & Excellent \\
\hline
\end{tabular}

Keterangan : $\mathrm{X}=$ Angka Kepuasan Pelanggan

Sumber: Nigel Hill, 2003

\section{Gap Analysis}

Gap Analysis Merupakan identifikasi adanya suatu perbedaan (disparity) antara satu hal dengan hal lainnya. Gap Analysis dihitung untuk mengukur kualitas pelayanan dengan perhitungan menggunakan rumus menurut Tjiptono (2002) : Kualitas pelayanan = Kinerja - Harapan. Jika bernilai positif $(+)$ berarti dalam 
kriteria baik dan jika bernilai negatif (-) bernilai buruk. Namun, penilaian hasil kesenjangan diinterpretasikan menurut menurut Parasuraman dkk. (1991). Jika nilai hasil kesenjangan >-1 berarti baik, dan nilai hasil <-1 berarti tidak baik.

\section{Hasil dan Pembahasan}

\subsection{Gambaran Umum Lokasi Penelitian}

Berdasarkan Peraturan Daerah Provinsi Bali No 16 Tahun 2009 tentang RTRW Provinsi Bali Tahun 2009-2029, Denpasar merupakan kota pada kawasan metropolitan Sarbagita dengan Kawasan Pusat Pemerintahan Provinsi Bali (Civic Center Provinsi) berada di Renon Kota Denpasar. Berdasarkan Peraturan Walikota Denpasar No. 28 Tahun 2013 tentang Penetapan Kawasan Niti Mandala Renon sebagai tempat pelaksanaan Hari Bebas Kendaraan Bermotor (Car Free Day) bahwa Pemerintah Kota Denpasar menetapkan Kawasan Niti Mandala Renon sebagai kawasan Hari Bebas Kendaraan Bermotor (Car Free Day). Terdapat tujuh ruas jalan yang dipakai sebagai areal pelaksanaan CFD antara lain Jalan Raya Puputan, Tantular, Cut Nyak Dien, S.Parman, Kusuma Atmaja, Basuki Rahmat dan Juanda. Namun, penelitian ini hanya pada empat ruas jalan yang menjadi akses utama menuju Lapangan Renon, Monumen Perjuangan Rakyat Bali.

\subsection{Pelaksanaan Car Free Day di Kawasan Renon}

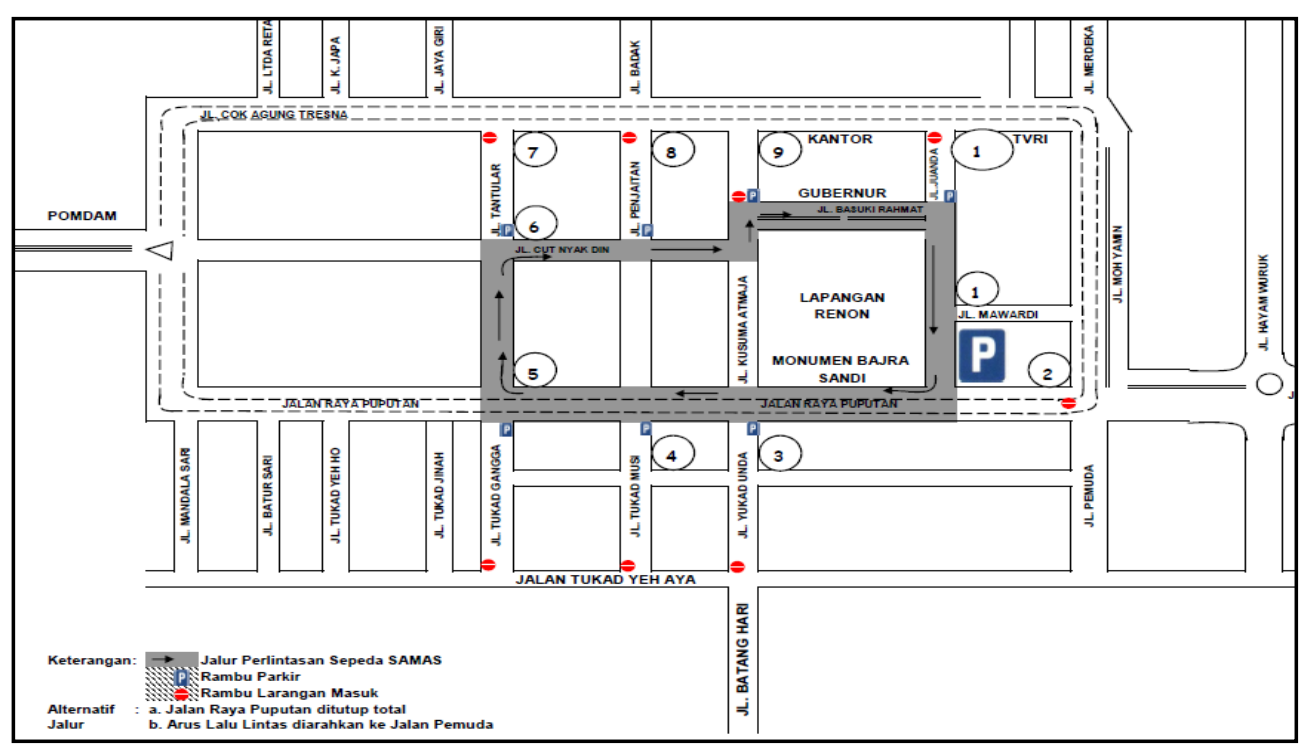

Gambar 2. Peta CFD Renon (Dinas Perhubungan, 2013)

Pelaksanaan kegiatan CFD di kawasan Renon Denpasar sudah dilakukan sejak tanggal 16 Agustus 2009. Maksud dari kegiatan CFD adalah untuk melestarikan kualitas lingkungan khususnya kualitas udara yang bersih dan sehat guna meminimalisir dampak dari Global Warming. Tujuan dari kegiatan CFD dibagi atas tujuan jangka pendek dan jangka panjang. Tujuan jangka pendek yaitu untuk membiasakan warga Kota berjalan kaki atau naik sepeda dan memberi kesempatan kepada masyarakat untuk berolahraga. Sedangkan tujuan jangka panjang yaitu untuk membangun karakter masyarakat perkotaan sehingga dapat mengurangi penggunaan kendaraan pribadi (Dinas Perhubungan, 2009).

\subsection{Perhitungan Kepuasan Pengunjung}

\subsubsection{Uji Validitas dan Reliabilitas}

Dalam uji validitas nilai ritung dan rtabel dari semua atribut pertanyaan pada kuesioner yang ada adalah valid, dikarenakan menurut Hair (dalam Handriati dkk., 2015) apabila $r_{\text {hitung }} \geq r_{\text {tabel }}$ maka butir pertanyaan pada kuesioner adalah valid. Jumlah responden sebanyak 90 menggunakan signifikansi $1 \%$ dengan nilai rtabel sebesar 0,267 . Dalam uji reliabilitas nilai rhitung dan rtabel dari semua atribut pertanyaan pada kuesioner yang ada adalah reliable, dikarenakan nilai $r_{\text {hitung }}$ pada atribut sebesar $0,819 \geq \mathrm{r}_{\text {tabel }}$ sebesar 0,267 . 


\subsubsection{Karakteristik responden}

Karakteristik responden dilihat dari usia pengunjung yang terbanyak adalah yang berusia 12-21 tahun. Dilihat dari pekerjaan pengunjung yang terbanyak adalah para pelajar. Dilihat dari pendidikan terakhir pengunjung yang terbanyak adalah Sekolah Menengah Atas (SMA). Dilihat dari jenis kelamin presentasi pengunjung laki-laki $42 \%$ dan perempuan $58 \%$. Dilihat dari domisili sebagian besar pengunjung berasal dari Kota Denpasar dengan presentase $78 \%$. Dilihat dari lama kunjungan,sebanyak $48 \%$ pengunjung menghabiskan waktu 2-3 jam. Dilihat dari frekuensi kunjungan, sebanyak $40 \%$ pengunjung mengunjungi areal Car Free Day setiap minggu pelaksanaan serta sebanyak 49\% pengunjung berkunjung dengan keluarga.

\subsubsection{Perhitungan Kepuasan dengan Costumer Satisfaction Index}

\section{Segmen 1: Jl. Basuki Rahmat}

Perkerasan jalan saat CFD berlangsung digunakan sebagai prasarana untuk berolah raga dan bermain misalnya lari, jogging, jalan santai, bersepeda dan skateboarding. Walaupun ruas jalan ini terbagi atas dua jalur yang dipisahkan oleh median, dimana salah satu jalur tetap berfungsi sebagai jalur sirkulasi kendaraan bermotor, pengunjung tidak perlu merasa khawatir karena terdapat beberapa petugas yang menjaga keamanan dan kenyamanan saat berkunjung. Sebagian badan jalan pada jalur ini digunakan sebagai kantong parkir untuk sepeda motor. Terdapat jalur pedestrian yang kanstinya digunakan untuk tempat duduk/ beristirahat (Gambar 3)

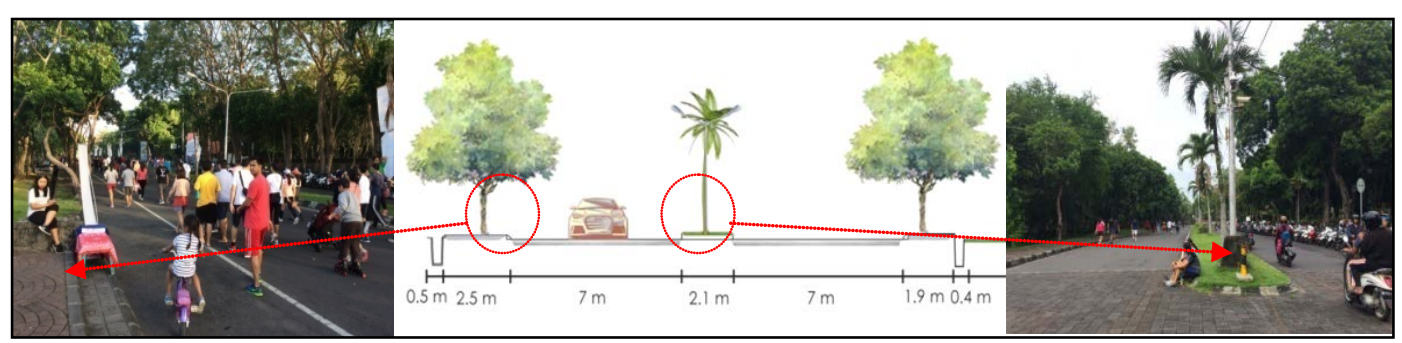

Gambar 3. Segmen 1: Jalan Basuki Rahmat

Sumber: Hasil Observasi, 2017

Atribut yang memiliki kinerja sangat puas adalah keamanan beraktivitas, kemudahan berinteraksi, kemudahan menikmati suasana. Kinerja yang tidak memuaskan adalah fasilitas pendukung, ragam pengelolaan dan kebersihan.Nilai kepuasan pengunjung CFD pada ruas jalan ini mencapai nilai 81,52\%. Nilai tersebut berada pada rentang $80 \%<X \leq 84 \%$ yang berarti "Good". Hal ini berarti atribut-atribut pelayanan lanskap jalan tersebut sudak cukup memuaskan bagi pengunjung.

Segmen 2: Jl Kusuma Atmaja

Perkerasan jalan saat CFD berlangsung digunakan sebagai prasarana untuk berolah raga dan bermain misalnya lari, jogging, jalan santai, bermain sepatu roda, skate board, bersepeda, bermain mobil listrik. Terdapat garis pemisah (lajur sepeda) yang sebenarnya bisa dimanfaatkan oleh pesepeda namun jarang dimanfaatkan oleh pesepeda pada saat CFD berlangsung. Pengunjung memanfaatkan bagian pedestrian untuk duduk beristirahat sehabis berolahraga, mengobrol santai, menunggu/ menemani anak bermain, atau makan makanan yang dibeli dari areal dagang di Jl. S Parman yang berhubungan langsung dengan koridor jalan ini (Gambar 4).

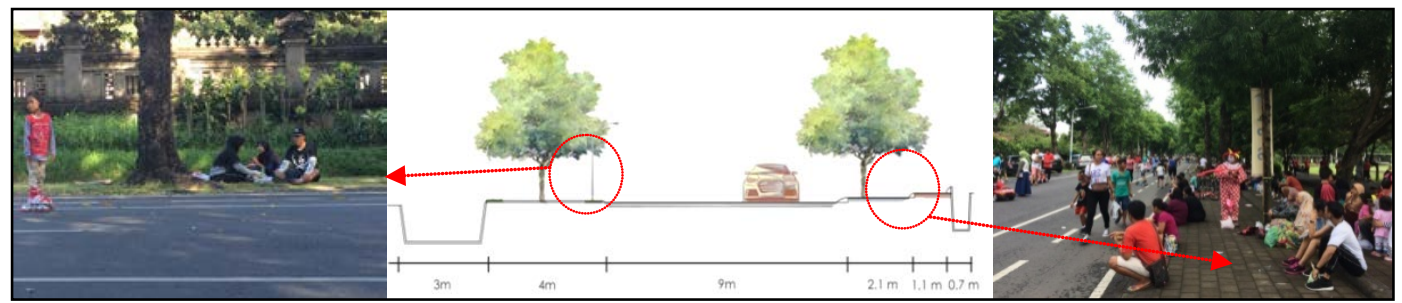

Gambar 4. Segmen 2: Jalan Kusuma Atmaja

Sumber: Hasil Observasi, 2017 
Atribut yang memiliki kinerja sangat puas adalah ragam aktivitas dan vegetasi. Kinerja yang tidak memuaskan merupakan ketersediaan parkir, dan fasilitas pendukung. Nilai kepuasan pengunjung CFD pada ruas jalan ini mencapai nilai $77 \%$. Nilai tersebut berada pada rentang $77 \%<X \leq 80 \%$ yang berarti "borderline" yang berarti terdapat tribut-atribut pelayanan lanskap jalan yang belum memuaskan.

Segmen 3: Jl Raya Puputan Niti Mandala

Perkerasan jalan saat CFD berlangsung digunakan sebagai prasarana untuk berolah raga dan bermain misalnya lari, jogging, jalan santai, bersepeda (anak-anak hingga lansia), skateboard, sepatu roda, scooter. Terdapat garis pemisah (jalur sepeda) yang sebenarnya bisa dimanfaatkan oleh pesepeda. Jalur hijau merupakan bagian dari lapangan karena terdapat pagar pembatas. Pengunjung yang berada pada ruas jalan tersebut memanfaatkan kanstin yang ada untuk tempat duduk/ beristirahat (Gambar 5).

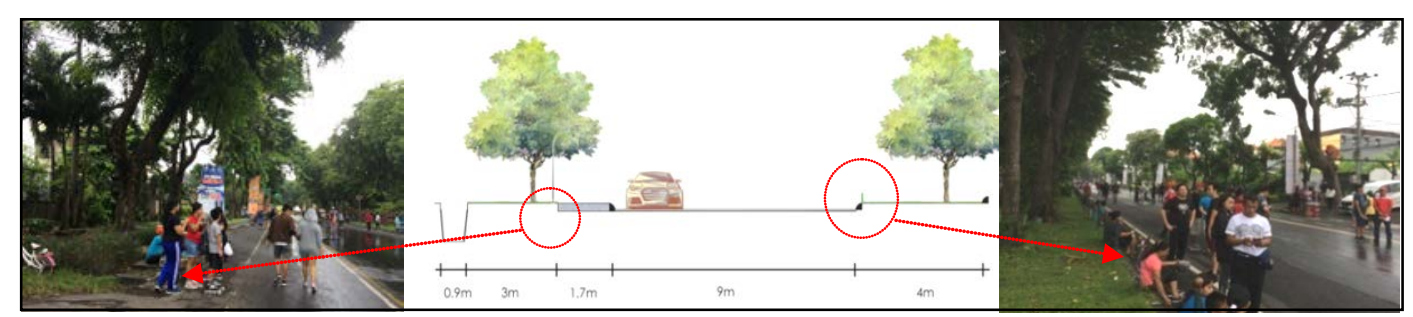

Gambar 5.Segmen 3: Jalan Raya Puputan Niti Mandala

Sumber: Hasil Observasi, 2017

Atribut yang memiliki kinerja sangat puas adalah ragam aktivitas dan kemudahan menikmati suasana dan perbaikan kualitas udara. Kinerja yang tidak memuaskan merupakan fasilitas pendukung dan ketersediaan lahan parkir. Nilai kepuasan pengunjung CFD pada ruas jalan ini mencapai nilai $75,65 \%$. Nilai tersebut berada pada rentang $71 \%<X \leq 77 \%$ yang berarti "cause for concern " yang berarti terdapat atributatribut pelayanan lanskap jalan yang belum memuaskan sehingga harus melakukan upaya lebih besar dan menciptakan strategi baru untuk membuat kondisi yang lebih baik.

Segmen 4:Jl Juanda Kartawijaya

Perkerasan jalan saat CFD berlangsung digunakan sebagai prasarana untuk berolah raga dan bermain misalnya lari, jogging, jalan santai, bersepeda (anak-anak hingga lansia), skateboard, dan sepatu roda. Terdapat fasilitas/ areal untuk parkir kendaraan namun kurang dimanfaatkan yaitu pada Parkir Timur Monumen Perjuangan Rakyat Bali (Bajrasandhi). Dikedua sisi jalan terdapat jalur pejalan kaki yang dimanfaatkan pengunjung untuk memarkirkan sepeda. Bagian kanstin dimanfaatkan sebagai tempat duduk (Gambar 6).

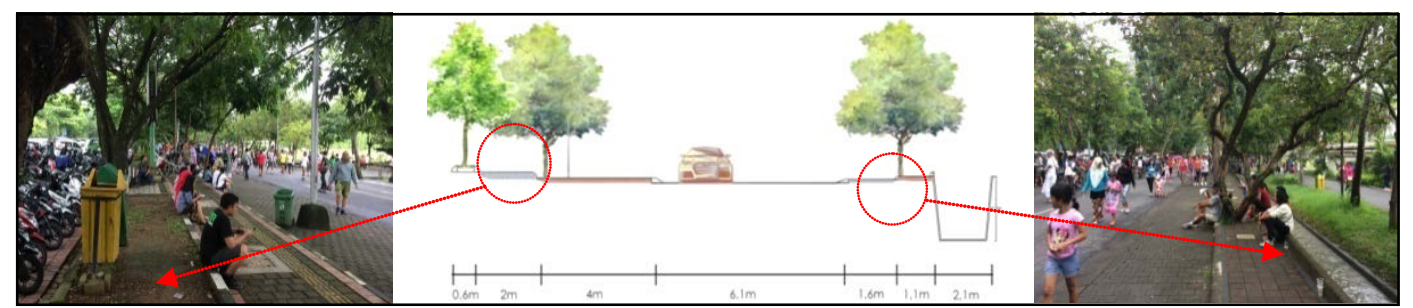

Gambar 6. Segmen 4: Jalan Juanda Kartawijaya

Sumber: Hasil Observasi, 2017

Atribut yang memiliki kinerja sangat puas adalah kebersihan dan perbaikan kualitas udara. Adapun kinerja yang tidak memuaskan merupakan fasilitas pendukung dan signage. Nilai kepuasan pengunjung CFD pada ruas jalan ini mencapai nilai $79,61 \%$. Nilai tersebut berada pada rentang $77 \%<X \leq 80 \%$ yang berarti "borderline". Tingkat Kepuasan Pengunjung Car Free Day Renon secara keseluruhan dapat dilihat pada Tabel 3. 
Tabel 3. Hasil Analisis CSI pada Car Free Day Renon

\begin{tabular}{llcccc}
\hline No. & \multicolumn{1}{c}{ Atribut } & MIS & WF(\%) & MSS & WS \\
\hline 1 & Vegetasi & 4,66 & 7,97 & 4,13 & 32,93 \\
2 & Keamanan beraktivitas & 4,62 & 7,90 & 4,00 & 31,59 \\
3 & Kebersihan & 4,74 & 8,10 & 3,70 & 29,98 \\
4 & Fasilitas Pendukung & 4,60 & 7,86 & 3,52 & 27,70 \\
5 & Kemudahan Akses & 4,48 & 7,66 & 3,83 & 29,36 \\
6 & Parkir & 4,58 & 7,83 & 3,62 & 28,36 \\
7 & Signage & 4,36 & 7,45 & 3,68 & 27,41 \\
8 & Ragam Aktivitas & 4,36 & 7,45 & 4,20 & 31,30 \\
9 & Kemudahan Berinteraksi & 4,57 & 7,81 & 4,04 & 31,60 \\
10 & Kemudahan Menikmati Suasana & 4,50 & 7,69 & 4,16 & 31,97 \\
11 & Perbaikan Kualitas Udara & 4,64 & 8,93 & 4,14 & 32,87 \\
12 & Memberikan Kepekaan Lingkungan & 4,51 & 7,71 & 3,97 & 30,58 \\
13 & Ragam Pengelolaan & 3,88 & 6,63 & 3,98 & 26,38 \\
& Jumlah & 58,50 & 100,00 & 50,98 & 392,01 \\
Costumer Satisfaction Index = 78,4\%(Borderline) & & & & \\
& S & & & &
\end{tabular}

Sumber : Hasil Penelitian, 2018

Dari hasiil perhitungan yang telah dilakukan, diperoleh nilai CSI keseluruhan pengunjung CFD Renon sebesar $78,4 \%$ yang berada pada rentang $77 \%<X \leq 80 \%$ berarti "borderline" atau berada pada ambang batas. Atribut yang memiliki kinerja sangat puas yaitu ragam aktivitas, perbaikan kualitas udara dan vegetasi. Sedangkan atribut yang kinerjanya kurang dan perlu ditingkatkan adalah fasilitas pendukung, parkir, dan signage.

\subsection{Analisis Kesenjangan (Gap Analysis)}

Analisis kesenjangan dilakukan pada setiap atribut layanan yang dinilai. Atribut layanan ditentukan berdasarkan variabel bebas dan indikator keberhasilan ruang terbuka publik menurut Carmona dkk. (2003) dan Project for Public Space (2004).

Tabel 4. Perhitungan Kesenjangan Per Atribut

\begin{tabular}{ccccc}
\hline No. & Atribut & $\begin{array}{c}\text { Mean } \\
\text { Importance }\end{array}$ & Mean Satisfaction & Gap \\
\hline 1 & Vegetasi & 4,66 & 4,13 & $-0,52$ \\
2 & Keamanan beraktivitas & 4,62 & 4,00 & $-0,62$ \\
3 & Kebersihan & 4,74 & 3,70 & $-1,04$ \\
4 & Fasilitas Pendukung & 4,60 & 3,52 & $-1,08$ \\
5 & Kemudahan Akses & 4,48 & 3,83 & $-0,64$ \\
6 & Parkir & 4,58 & 3,62 & $-0,96$ \\
7 & Signage & 4,36 & 3,68 & $-0,68$ \\
8 & Ragam Aktivitas & 4,36 & 4,20 & $-0,16$ \\
9 & Kemudahan Berinteraksi & 4,57 & 4,04 & $-0,53$ \\
10 & Kemudahan Menikmati Suasana & 4,50 & 4,16 & $-0,34$ \\
11 & Perbaikan Kualitas Udara & 4,64 & 4,14 & $-0,50$ \\
12 & Memberikan Kepekaan Lingkungan & 4,51 & 3,97 & $-0,54$ \\
13 & Ragam Pengelolaan & 3,88 & 3,98 & 0,10 \\
\hline
\end{tabular}

Sumber : Hasil Penelitian, 2018

Berdasarkan analisis Gap (Tabel 5), dapat dibahas berdasarkan Indikator yaitu;

1. Kenyamanan dan Kesan

Atribut yang merupakan indikator kenyamanan dan kesan adalah vegetasi, keamanan beraktivitas, kebersihan, dan fasilitas pendukung.

a. Vegetasi atau tanaman yang terdapat pada lanskap jalan dianggap oleh pengunjung sangat penting dalam mendukung kinerja lanskap jalan $(4,66)$. Sedangkan tingkat kinerja atau kepuasan yang 
pengunjung rasakan sudah cukup baik $(4,13)$ dengan nilai kesenjangan sebesar $-0,52$. Walaupun analisis Gap menunjukkan nilai negatif, menurut Parasuraman (1991), jika hasil kesenjangan <-1 berarti baik, dan hasil >-1 berarti tidak baik. Nilai kesenjangan -0,52<-1 berarti sudah baik.

b. Keamanan beraktivitas pada lanskap jalan dianggap oleh pengunjung sangat penting $(4,62)$. Sedangkan tingkat kinerja atau kepuasan yang pengunjung rasakan sudah cukup baik $(4,00)$ dengan nilai kesenjangan sebesar -0.62 yang berarti sudah baik.

c. Kebersihan pada lanskap jalan dianggap oleh pengunjung sangat penting $(4,74)$. Sedangkan tingkat kinerja atau kepuasan yang pengunjung rasakan belum cukup baik $(3,70)$ dengan nilai kesenjangan sebesar -1,04 (-1,04 > -1) yang berarti tidak baik. Dengan kondisi ini, secepatnya perlu dilakukan upaya maupun strategi untuk mengatasi masalah kebersihan pada lanskap jalan areal CFD berlangsung.

d. Fasilitas pendukung pada lanskap jalan dianggap oleh pengunjung sangat penting $(4,60)$. Sedangkan tingkat kinerja atau kepuasan yang pengunjung rasakan belum cukup baik $(3,52)$ dengan nilai kesenjangan sebesar -1,08 (-1,08>-1) yang berarti tidak baik. Dengan kondisi ini, perlu dilakukan pertimbangan penyediaan fasilitas pendukung yang dapat mendukung kegiataan CFD namun tidak menganggu fungsi utama dari lanskap jalan tersebut.

2. Akses dan Hubungan

Atribut yang merupakan indikator akses dan hubungan adalah kemudahan akses, parkir dan signage (tanda).

a. Kemudahan Akses dianggap oleh pengunjung sangat penting $(4,48)$ sedangkan tingkat kinerja atau kepuasan yang pengunjung rasakan sudah cukup baik $(3,83)$ dengan nilai kesenjangan sebesar 0,64 .

b. Parkir dianggap oleh pengunjung sangat penting $(4,58)$ sedangkan tingkat kinerja atau kepuasan yang pengunjung rasakan sudah cukup baik $(3,62)$ dengan nilai kesenjangan sebesar $-0,96$.

c. Signage dianggap oleh pengunjung sangat penting $(4,36)$ sedangkan tingkat kinerja atau kepuasan yang pengunjung rasakan sudah cukup baik $(3,68)$ dengan nilai kesenjangan sebesar $-0,68$.

3. Fungsi dan Aktivitas

Atribut yang merupakan indikator fungsi dan aktivitas sosial adalah kemudahan berinteraksi, ragam aktivitas dan kemudahan menikmati suasana.

a. Ragam aktivitas pada lanskap jalan dianggap oleh pengunjung sangat penting $(4,36)$ sedangkan tingkat kinerja atau kepuasan yang pengunjung rasakan sudah cukup baik $(4,20)$ dengan nilai kesenjangan sebesar $-0,16$.

b. Kemudahan berinteraksi pada lanskap jalan dianggap oleh pengunjung sangat penting $(4,57)$ sedangkan tingkat kinerja atau kepuasan yang pengunjung rasakan sudah cukup baik $(4,04)$ dengan nilai kesenjangan sebesar $-0,53$.

c. Kemudahan menikmati suasana pada lanskap jalan dianggap oleh pengunjung sangat penting $(4,50)$ sedangkan tingkat kinerja atau kepuasan yang pengunjung rasakan sudah cukup baik $(4,16)$ dengan nilai kesenjangan sebesar $-0,34$.

4. Penemuan dan Pengelolaan

Atribut yang merupakan indikator penemuan dan pengelolaan adalah perbaikan kualitas udara, memberikan kepekaan lingkungan dan ragam pengelolaan.

a. Perbaikan kualitas udara dianggap oleh pengunjung sangat penting $(4,64)$ sedangkan tingkat kinerja atau kepuasan yang pengunjung rasakan sudah cukup baik $(4,14)$ dengan nilai kesenjangan sebesar $-0,50$.

b. Memberi kepekaan terhadap lingkungan dianggap oleh pengunjung sangat penting $(4,51)$ sedangkan tingkat kinerja atau kepuasan yang pengunjung rasakan sudah cukup baik $(3,97)$ dengan nilai kesenjangan sebesar $-0,54$.

c. Ragam pengelolaan dianggap oleh pengunjung penting $(3,68)$ sedangkan tingkat kinerja atau kepuasan yang pengunjung rasakan sudah baik $(3,98)$ dengan nilai kesenjangan sebesar 0,10 yang berarti sudah baik. Kinerja atau kepuasan yang pengunjung rasakan sudah melampaui tingkat harapan pengunjung. 


\subsection{Evaluasi dan Rekomendasi}

Menurut Carr et al (dalam Carmona 2003) kenyamanan merupakan syarat mutlak keberhasilan ruang publik dimana dipengaruhi oleh ketersediaan fasilitas pendukung. Fasilitas Pendukung pada CFD di kawasan Renon sangat dibutuhkan oleh masyarakat namun penyediaannya kurang maksimal. Fasilitas pendukung yang dimaksud adalah fasilitas yang dapat mendukung kegiatan atau aktivitas pada program CFD. Beberapa fasilitas pendukung yang perlu ditambahkan yaitu tong sampah (sekaligus mendukung atribut kebersihan), toilet umum dan rambu untuk pesepeda. Fasilitas pendukung yang perlu ditambahkan dapat bersifat sementara atau permanen. Namun, perlu diperhatikan untuk penambahan fasilitas pendukung tidak mengurangi fungsi utama lanskap jalan yaitu sebagai ruang sirkulasi.

Berdasarkan Pedoman Perencanaan dan Pengoperasian Fasilitas Parkir tahun 1998 oleh Dirjen Perhubungan darat, penyediaan tempat-tempat parkir di pinggir jalan pada lokasi jalan tertentu baik di badan jalan maupun dengan menggunakan sebagian dari perkerasan jalan, mengakibatkan turunnya kapasitas jalan, terhambatnya arus lalu lintas dan penggunaan jalan menjadi tidak efektif. Penggunaan Kantung Parkir yang menggunakan badan jalan dapat dikurangi dengan memanfaatkan areal parkir Perkantoran yang ada misalnya Kantor Gubernur Bali dan Dinas Kebudayaan yang berada di sebelah utara Lapangan Renon, Kanor DPRD Provinsi Bali di sebelah barat Lapangan Renon, dan optimalisasi pemanfaatan Parkir Timur Lapangan Renon.

\section{Simpulan dan Saran}

Tingkat kepuasan pengunjung Car Free Day di Kawasan renon mencapai nilai $78.4 \%$ yang berada pada rentang $77 \%<X \leq 80 \%$ yang berarti "borderline". Hal ini berarti terdapat beberapa atribut yang belum memuaskan. Berdasarkan Customer Satisfaction Index (CSI), Gap Analysis atribut-atribut yang memiliki nilai kesenjangan besar dan perlu dilakukan perbaikan adalah fasilitas pendukung, kebersihan dan parkir. Atribut yang perlu dipertahankan dan bisa ditingkatkan kinerjanya adalah vegetasi, keamanan beraktivitas, kemudahan berinteraksi, kemudahan menikmati suasana, perbaikan kualitas udara dan fungsi CFD dalam memberikan kepekaan lingkungan.

\section{Daftar Pustaka}

Carmona, M., S. Tiesdell, T. Health, T., and T. Oc. 2003. Public Space Urban Space: The Dimension of Urban Design. Architectural Press. London.

Dinas Perhubungan Kota Denpasar. 2009. Proposal Car Free Day. Denpasar

Handriati, A., Sunaryo, V. Heliam. 2015. Analisis Kualitas Pelayanan Publik Terhadap Kepuasan Kosumen dengan Menggunakan Metode Servperf-IPA-CSI. E-Jurnal Fakultas Teknologi Industri. 21(4): 178-190.

Parasuraman A., A. Valarie, A. Leonard, L. Leonard, and Berry. 1985. A Conceptual Model of Service Quality and its Implications for Future Research. Journal of Marketing. 49: 41-50.

Pemerintah Kota Denpasar. 2013. Peraturan Wali Kota Denpasar Nomor 28 tahun 2013 Tentang penetapan Kawasan Niti Mandala Renon Sebagai Tempat Pelaksanaan Hari bebas kendaraan bermotor (Car Free Day) .Denpasar.

Pemerintah Provinsi Bali. 2009. Peraturan Daerah Nomor 16 tahun 2009 Tentang RTRW Provinsi Bali Tahun 2009-2029. Bali

Poewarti, T., E. Santosa, M. Liko'a. 2016. Perhitungan Kepuasan Pengunjung terhadap Kinerja Ruang Publik Menggunakan Customer Statisfaction Index (CSI). Dalam:Temu Ilmiah Iplbi. Fakultas Teknik Sipil dan Perencanaan (FTSP). Institut Teknologi Nasional Malang. Malang.

Project For Public Space. 2005. What Makes A Successful Place?. Placemaking Resources. Tersedia online di https://www.pps.org/article/grplacefeat (diakses tanggal 28 Oktober 2017).

Rangkuti, F. 2003. Measuring Customer Satisfaction: Teknik Mengukur \& Strategi Meningkatkan Kepuasan Pelanggan \& Analisis Kasus PLN JP. Gramedia Pustaka Utama .Jakarta.

Republik Indonesia. 1996. Keputusan Menteri Lingkungan Hidul Nomor 15 tahun 1996 tentang Program Langit Biru. Menteri Negara Lingkungan Hidup. Jakarta 
Republik Indonesia. 1998. Pedoman Perencanaan dan Pengoperasian Fasilitas Parkir. Direktorat Jendral Pehubungan Darat. Jakarta

Suryana, I.G.P.E.2015. Analisis Ketersediaan RTH dan Indeks Kenyamanan (Kasus Kota Denpasar tahun 2003 dan 2013).M.Sc. Tesis (Tidak dipublikasikan). Universitas Gajah Mada. Yogyakarta. Tjiptono, F., Gregorius, C.2011. Service, Quality \& Satisfaction. Andi Offset. Yogyakarta

Tjiptono, F. 2002. Manajemen Jasa Edisi I. Andi Offset. Yogyakarta. 